\title{
SHORT-TERM STIMULATORY EFFECT OF SERTOLI CELL CONDITIONED MEDIUM ON LEYDIG CELL STEROIDOGENESIS IS NOT MEDIATED BY INHIBIN
}

\author{
A. J. Grootenhuis,* R. Melsekt, M. A. Timmerman, J. W. Hoogerbrugge, F. F. G. Rommerts \\ and F. H. DE JONG \\ Department of Biochemistry (Division of Chemical Endocrinology), Erasmus University Rotterdam, \\ Rotterdam, The Netherlands
}

(Received 20 November 1989)

\begin{abstract}
Summary - Addition of concentrated rat Sertoli cell conditioned medium (rSCCM) to isolated Leydig cells from immature rats stimulated steroid production more than 13-fold within $4 \mathrm{~h}$. LH-stimulated steroidogenesis was not enhanced by addition of rSCCM. The biological activity of the concentrated ISCCM was higher after incubation of Sertoli cells with FSH, whereas FSH alone did not stimulate steroid production. This effect of rSCCM was not due to inhibin, since highly purified $32 \mathrm{kDa}$ rat inhibin, in doses equivalent to those present in rSCCM, had no effect on steroidogenesis during the $4 \mathrm{~h}$ incubation period. Furthermore, inhibin could be separated from the Leydig cell stimulating factor by anion-exchange chromatography. These results indicate a short-term paracrine control of Leydig cell steroidogenesis by Sertoli cell derived factors, which differ from inhibin.
\end{abstract}

\section{INTRODUCTION}

Luteinizing hormone $(\mathrm{LH})$ is the main regulator of Leydig cell steroidogenesis. However, there is abundant evidence, both from in vivo and in vitro experiments, that locally produced factors can modulate Leydig cell activity and that these factors are produced by cells in the seminiferous tubuli and by Sertoli cells in particular [1, 2]. In hypophysectomized immature rats, in vivo administration of follicle-stimulating hormone (FSH) can induce Leydig cell hypertrophy and stimulate steroidogenic activity [3-5]. It is likely that this effect is mediated by Sertoli cells, since these are the only testicular cells containing FSH receptors [6]. Seminiferous tubule damage induced by different procedures (antifertility compounds [7], hydroxyurea, fetal irradiation [8] or cryptorchidism [9]) causes hypertrophy of Leydig cells. Factors which can stimulate or inhibit basal and/or LH stimulated Leydig cell steroidogenesis in vitro have been shown to be present in Sertoli cell conditioned medium (SCCM) [10-13], in medium from cultured seminiferous tubules $[13,14]$ and in testicular interstitial fluid $[15,16]$. Most of these authors reported relatively small effects after long-term incubations (up to $48 \mathrm{~h}$ ) of Leydig cells with the added materials.

There is only little information on the molecular composition of the Leydig cell modulating factor(s)

*To whom correspondence should be addressed: Dr A. J. Grootenhuis, Department of Biochemistry II, Erasmus University Rotterdam, P.O. Box 1738, 3000 DR Rotterdam, The Netherlands. secreted by Sertoli cells. It has been shown that the active compound from rat interstitial fluid is likely to be rat serum albumin $[16,17]$. Possible Lcydig ccll modulating factors in SCCM are inhibin and activin, gonadal hormones composed of two subunits $(\alpha \beta$ and $\beta \beta$ respectively), which have been purified on the basis of their suppressive and stimulatory effects on FSH release from cultured rat pituitary cells, respectively [18]. It has been shown that Sertoli cells secrete inhibin [19-21], and a $32 \mathrm{kDa} \alpha \beta$-B inhibin dimer has been purified from rat SCCM [22]. Inhibin has been reported to stimulate basal and human chorionic gonadotrophin (hCG)-induced testosterone production by cultured immature and neonatal rat Leydig cells respectively in long-term cultures; activin can counteract these effects $[23,24]$.

The purpose of the present study was to investigate whether inhibin is also one of the components in SCCM which can influence Leydig cell steroid production during short-term incubations.

\section{MATERIALS AND METHODS}

\section{Sertoli cell conditioned medium}

Sertoli cells were isolated from the testes of 22-dayold Wistar rats and were cultured for 1 day in plastic $150 \mathrm{~cm}^{2}$ flasks (Costar, Cambridge, Mass, U.S.A.) in Eagle's minimal essential medium (MEM; Gibco, Grand Island, N.Y., U.S.A.) containing $1 \%(\mathrm{v} / \mathrm{v})$ fetal calf serum (FCS; Gibco) as described [22]. On the following day the attached Sertoli cells were 
washed and cultured further in $20 \mathrm{ml}$ MEM without FCS or other additions in the presence or absence of human FSH (hFSH, $25 \mathrm{mU} / \mathrm{ml}$; Metrodin, Serono, Geneva, Switzerland). According to the manufacturer, this preparation contains less than $1 \mathrm{U}$ of LH per $75 \mathrm{U}$ of FSH. Media were renewed after 3 or 4 day periods and cultures were terminated after $4-5$ weeks. Collected control and hFSH-stimulated rat SCCM (CrSCCM and FrSCCM) were stored at $-20^{\circ} \mathrm{C}$. After thawing media were pooled, concentrated 50 -fold by diafiltration, exchanged with $5 \mathrm{ml}$ MEM using disposable cartridges with YM10 membranes (molecular weight cut-off at $10 \mathrm{kDa}$; Amicon, Lexington, Mass, U.S.A.) and added to the incubation medium of Leydig cells (see below). Protein concentrations in the 50-fold concentrated $\mathrm{CrSCCM}$ and FrSCCM, were 1.42 and $2.18 \mathrm{mg} / \mathrm{ml}$, respectively, as measured using the protein assay kit purchased from Biorad (München, F.R.G.). As a preliminary characterization of the Leydig cell stimulating activity $\mathrm{CrSCCM}$ was chromatographed on a Mono $Q$ anion exchange chromatography column (Pharmacia, Uppsala, Sweden), using the buffers described previously [22].

Bioactive and immunoactive inhibin were measured in CrSCCM [25], using a bovine follicular fluid (bFF) preparation with an arbitrary potency of $1 \mathrm{U} / \mu \mathrm{g}$ protein as a standard. One unit of this standard reduces FSH release from rat pituitary cells in vitro to $57.6 \pm 2.5 \%$ (mean $\pm \mathrm{SD} ; n=10$ ) of the control secretion. The International Research Standard for Inhibin $(86 / 690)$ has a relative specific activity of $60 \pm 10 \mathrm{U} / \mu \mathrm{g}$ (mean $\pm \mathrm{SEM} ; n=5$ ) expressed in units of this bFF standard [22]. Inhibin with a molecular weight of $32 \mathrm{kDa}$ was purified from a pool of CrSCCM by Amicon YM10 diafiltration, Mono $Q$ anion-exchange, cl/c8 reversed phase chromatography and SDS-PAGE as described previously [22]. The relative specific activity of this material was $16.4 \times 10^{6} \mathrm{U} / \mathrm{mg}$ protein [22].

\section{Leydig cell incubations}

Leydig cells were isolated from testes obtained from 21-22-day-old Wistar rats as described [26]. The Leydig cells $\left(0.5 \times 10^{5}\right.$ per well $)$ attached to the surface of 96-well plates (Costar) during a $1 \mathrm{~h}$ incubation in MEM with $0.1 \%$ bovine serum albumin (Sigma, St Louis, Mo., U.S.A.). After washing, the cells were incubated in a total volume of $200 \mu \mathrm{l}$ medium without BSA, in the presence of inhibitors of pregnenolone (3 $\beta$-hydroxy-5-pregnen20 -one) metabolism ( $5 \mu \mathrm{M}$ cyanoketone and $20 \mu \mathrm{M}$ SU-10603) for $4 \mathrm{~h}$ at $32 \mathrm{C}$ in $5 \% \quad \mathrm{CO}_{2} /$ air [27]. Various amounts $(0.4-40 \mu \mathrm{l})$ of 50 -fold concentrated $\mathrm{CrSSCM}$ and $32 \mathrm{kDa}$ inhibin were added in the absence or presence of ovine LH (final concentration $20 \mathrm{ng} / 200 \mu \mathrm{l}$; NIH-LH-S-18). Pregnenolone in culture media was measured by radioimmunoassay [27].

\section{RESULTS}

During the $4 \mathrm{~h}$ incubation, pregnenolone production by incubated immature Leydig cells was stimulated in a dose-dependent fashion after addition of CrSCCM (Fig. 1). Various amounts of highly purified $32 \mathrm{kDa}$ inhibin had no effect. Since $1 \mathrm{U}$ of purified $32 \mathrm{kDa}$ inhibin reduces pituitary $\mathrm{FSH}$ release by $57.6 \%$, the amount of inhibin added to the Leydig cells with the highest dose $(400 \mathrm{U} /$ well) is rather large. In the presence of a maximally stimulating dose of LH, CrSCCM (Fig. 1) or $32 \mathrm{kDa}$ inhibin had no further effect (not shown). With three different Sertoli and Leydig cell preparations the stimulation of steroid production with $20 \mu 1$ of 50 -fold concentrated CrSCCM was $21 \pm 5.8$-fold (mean \pm SEM).

Subsequently, the effect of hFSH on the release of the Leydig cell stimulating activity from Sertoli cells was studied. CrSCCM from the first collection period (day 1-3 after attachment of Sertoli cells) stimulated basal Leydig cell steroid production in a dose-dependent manner (Fig. 2). Media from hFSH-stimulated Sertoli cells (FrSCCM) were 1.5-3 times more potent than CrSCCM. Human FSH itself, in a concentration present in the highest dose of FrSCCM had no significant effect on Leydig cell steroid production (Student's $t$-test; Fig. 2).

The secretion of the Leydig cell stimulating factor and the effect of FSH on its secretion diminished with increasing culture period of the Sertoli cells. CrSCCM collected during the first two weeks (4 collections) stimulated basal steroid production and FSH enhanced the biological activity. Thereafter, no effect of FSH on the steroid stimulatory activity was found. In contrast immunoreactive inhibin-like activity was still produced; its production could still be stimulated by addition of FSH (Table 1).

Finally, the fractions of CrSCCM, obtained after chromatography on a Mono $Q$ anion-exchange column, were tested for Leydig cell stimulating activity. The bulk of the activity was eluted from the column in fractions 4,5 and 6 at $\mathrm{NaCl}$ concentrations between 25 and $75 \mathrm{mmol} / \mathrm{l}$, whereas the inhibin bioactivity was eluted in fractions $8-11$, at a salt concentration between 100 and $180 \mathrm{mmol} / 1$.

\section{DISCUSSION}

The results of the present study show that immature rat Sertoli cells in culture secrete a factor or factors stimulating basal steroidogenesis in Leydig cells within $4 \mathrm{~h}$. The amount of this Leydig cell steroidogenesis stimulating activity in the medium of cultured Sertoli cells is increased after incubation of Sertoli cells with FSH. The stimulation of Leydig cell steroidogenesis is not due to the presence of inhibin in the medium.

In most of the earlier reports on Leydig cell stimulating factors produced by testicular cells, Leydig cells were incubated for periods of $5-48 \mathrm{~h}$ with 


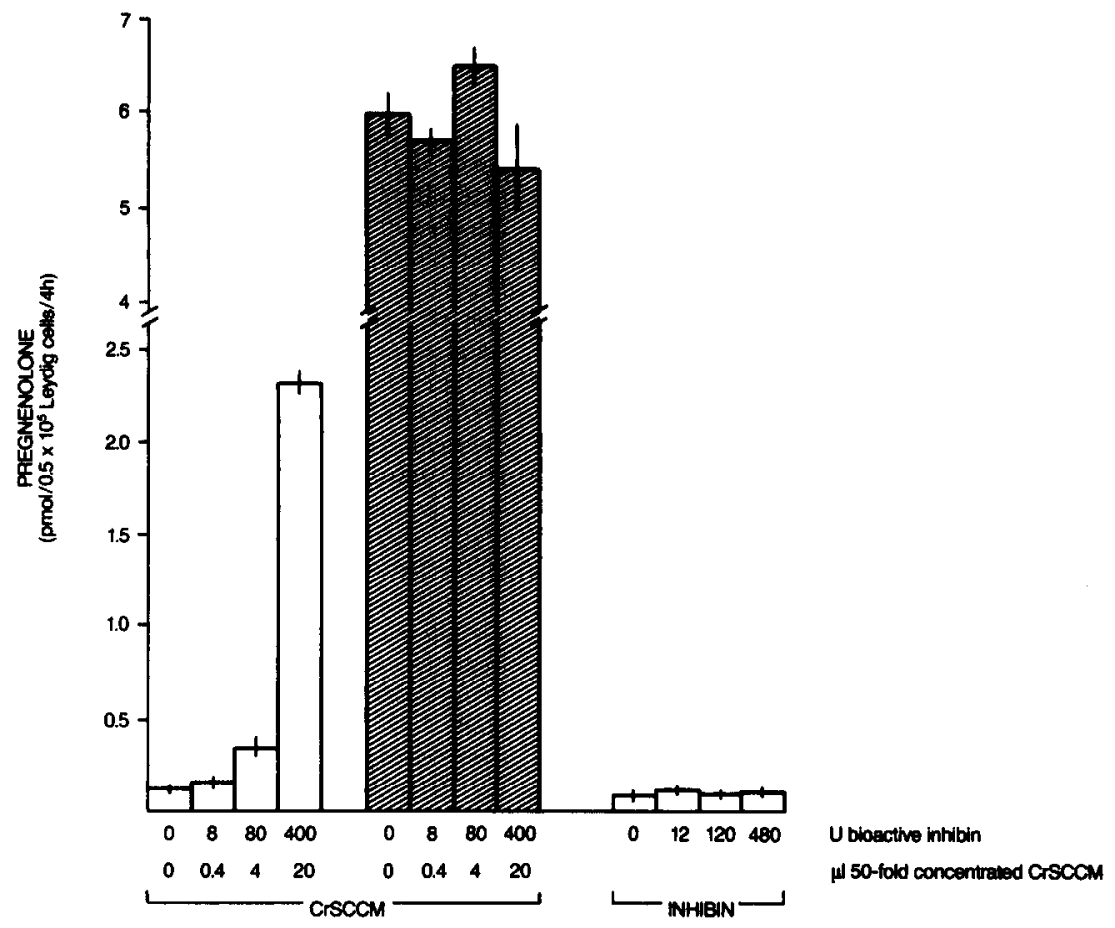

Fig. 1. Effects of increasing doses of control rat Sertoli cell conditioned medium (CrSCCM) or highly purified $32 \mathrm{kDa}$ inhibin (inhibin) on pregnenolone production in $4 \mathrm{~h}$ by immature Leydig cells incubated without (open bars) or with LH (hatched bars). Sertoli cell media were 50 -fold concentrated and exchanged, and 0.4-20 $\mu$ lof concentrated CrSCCM was added per $200 \mu$ l. Values are means \pm SEM from triplicate incubations.

spent media of tubuli or Sertoli cells and rather small effects were observed. In these studies Leydig cell steroid production may have been influenced by cxhaustion of nutrients in the culture media. To avoid these problems, rSCCM was concentrated and exchanged in the present study. The maximal effect of $\mathrm{rSCCM}$ on Leydig cell steroidogenesis was much larger than reported by others $[10,11,13]$ and comparable with the response to a maximally active dose of LH. We have not observed any additional effect of rSCCM on LH-stimulated steroid production of immature Leydig cells.

Although the medium was derived from cultured Sertoli cells, the origin of the stimulatory activity has

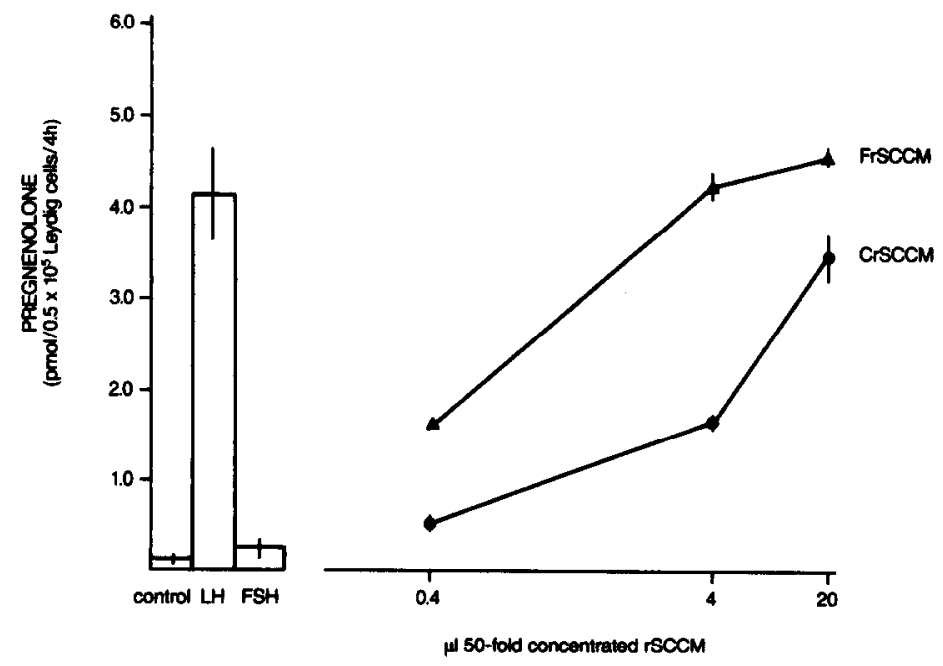

Fig. 2. Effects of a $4 \mathrm{~h}$ incubation with increasing concentrations of control and FSH $(25 \mathrm{mU} / \mathrm{ml})$ stimulated rat Sertoli cell conditioned medium (CrSCCM and FrSCCM respectively) collected during the first 3 days of culture on pregnenolone production by immature Leydig cells. The effects of $100 \mathrm{ng} / \mathrm{ml} \mathrm{LH}$ and the highest dose of FSH $(125 \mathrm{mU} / \mathrm{ml})$ on pregnenolone production are also shown. Values are means \pm SEM from triplicate incubations. 
Table 1. Time-dependent and FSH-induced secretion of Leydig cell steroidogenesis stimulating factor and inhibin-like immunoreactivity by cultured immature rat Sertoli cells

\begin{tabular}{ccccc}
\hline & \multicolumn{2}{c}{$\begin{array}{c}\text { Stimulation factor } \\
\text { of Leydig cell } \\
\text { steroidogenesis } \\
\text { Collection } \\
\text { period }\end{array}$} & $\begin{array}{c}\text { after addition of } \\
\text { CrSCCM }\end{array}$ & \multicolumn{2}{c}{$\begin{array}{c}\text { Relative amount } \\
\text { FrSCCM } \\
\text { immunoin-like } \\
\text { present in }\end{array}$} & CrSCCM & FrSCCM \\
\hline 1 & 16.2 & 20.6 & $100 \%$ & $156 \%$ \\
2 & 7.0 & 18.9 & $99 \%$ & $225 \%$ \\
3 & 6.4 & 28.8 & $87 \%$ & $280 \%$ \\
4 & 12.1 & 19.5 & $82 \%$ & $144 \%$ \\
5 & 2.4 & 2.8 & $41 \%$ & $136 \%$ \\
6 & 1.8 & 1.9 & $24 \%$ & $243 \%$ \\
7 & 1.7 & 2.0 & $37 \%$ & $195 \%$ \\
\hline
\end{tabular}

Media from Sertoli cells cultured in the absence (CrSCCM) or presence of FSH (FrSCCM) were collected during a period of $3 \frac{1}{2}$ weeks ( 7 half-weekly collections), concentrated 50 -fold and tested in a dose of $20 \mu 1$ per $200 \mu \mathrm{l}$ medium for their effects on basal immature Leydig cell pregnenolone production. Results are expressed as stimulation factor, compared with basal production. In these concentrated media the amount of inhibinlike immunorcactivity was also determined (expressed as \% of CrSCCM (period 1 ); $100 \%=60 \mathrm{U} / \mathrm{ml}$ unconcentrated media).

not yet been determined unequivocally. The Sertoli cell preparations were not completely pure, as peritubular and germinal cells were also present. The fact that FSH can stimulate the secretion of this factor, however, is a strong indication that the factor is a Sertoli cell product, since only Sertoli cells have FSH receptors. These characteristics indicate that this factor may be a mediator of the effects of FSH on Leydig cells in vivo.

The nature of the biologically active factor(s) is not known, although it has been shown that Leydig cell stimulating activity is heat sensitive, and associated with a compound with a molecular mass larger than $10 \mathrm{kDa}[10,13]$. We also found that the Leydig cell stimulating activity is retained by a membrane with a molecular weight cut off at $10 \mathrm{kDa}$; the activity could be separated from inhibin by anion exchange chromatography. Inhibin has been reported to increase hCG-induced steroid production from neonatal rat Leydig cells [23], to stimulate basal but not hCG-induced steroid production from immature rat Leydig cells [24] and to have no effect on basal or hCG-stimulated steroid production from mature rat Leydig cells [28]. On basis of these reports and the present observations we postulate that inhibin may act as a trophic regulator of Leydig cell function and is not involved in short-term regulation of steroid production.

The physiological importance and identity of these factors have not yet been established. However, these results suggest short-term paracrine control of Leydig cell steroidogenesis by Sertoli cell derived factors.

Acknowledgement - This work was supported in part by the Dutch Foundation for Medical Research (FUNGO). We are grateful to the NIADDK, Bethesda, Md, U.S.A. for the supply of LII.

\section{REFERENCES}

1. Risbridger G. P. and de Kretser D. M.: Paracrine regulation of the testis. In The Testis (Edited by
H. Burger and D. de Kretser). Raven Press, New York (1989) pp. 255-268.

2. Sharpe R. M.: Intratesticular factors controlling testicular function. Biol. Reprod. 30 (1984) 29-49.

3. Odell W. D. and Swerdloff R. S.: Etiologies of sexual maturation: a model system based on sexually maturing rat. Recent Prog. Horm. Res. 32 (1976) 245-288.

4. Van Beurden W. M. O., Roodnat B., de Jong F. H., Mulder E. and Van der Molen H. J.: Hormonal regulation of LH stimulation of testosterone production in isolated Leydig cells of immature rats: the effect of hypophysectomy, FSH and estradiol-17 $\beta$. Steroids 28 (1976) 847-865.

5. Teerds K. J., Closset J., Rommerts F. F. G., de Rooij D. G., Stocco D. M., Colenbrander B., Wensing C. J. G. and Hennen G.: Effects of pure FSH and LH preparations on the number and function of Leydig cells in immature hypophysectomized rats. J. Endocr. 120 (1989) 97-106.

6. Thanki K. H. and Steinberger A.: Effect of age and hypophysectomy on FSH binding by rat testes. $A n-$ drologia 10 (1978) 195-202.

7. Aoki A. and Fawcett D. W.: Is there a local feedback from the seminiferous tubules affecting activity of the Leydig cells? Biol. Reprod. 19 (1978) 144-158.

8. Rich K. A., Kerr J. B. and de Kretser D. M.: Evidence for Leydig cell dysfunction in rats with seminiferous tubule damage. Molec. Cell. Endocr. 13 (1979) 123-135.

9. Risbridger G. P., Kerr J. B. and de Kretser D.M.: Evaluation of Leydig cell function and gonadotropin binding in unilateral and bilateral cryptorchidism: evidence for local control of Leydig cell function by the seminiferous tubule. Biol. Reprod. 24 (1981) 534-540.

10. Verhoeven G. and Cailleau J.: A factor in spent media from Sertoli cell-enriched cultures that stimulates steroidogenesis in Leydig cells. Molec. Cell. Endocr. 40 (1985) 57-68.

11. Benahmed M., Grenot C., Tabone E., Sanchez P. and Morera A. M.: FSH regulates cultured Leydig cell function via Sertoli cell proteins: an in vitro study. Biochem. Biophys. Res. Commun. 132 (1985) 729-734.

12. Benahmed M., Morera A. M. and Chauvin M. A.: Evidence for a Sertoli cell, FSH-suppressible inhibiting factor(s) of testicular steroidogenic activity. Biochem. Biophys. Res. Commun. 139 (1986) 169-178.

13. Papadopoulos V., Kamtchouing P., Drosdowsky M. A., Hochereau de Reviers M. T. and Carreau S.: Adult rat Sertoli cells secrete a factor or factors which modulate Leydig cell function. $J$. Endocr. 114 (1987) 459-467.

14. Syed V., Khan S. A. and Ritzen E. M.: Stage-specific inhibition of interstitial cell testosterone secretion by rat seminiferous tubules in vitro. Molec. Cell. Endocr. $\mathbf{4 0}$ (1985) 257-264.

15. Sharpe R. M. and Cooper I.: Intratesticular secretion of a factor(s) with major stimulatory effects on Leydig cell testosterone secretion in vitro. Molec. Cell. Endocr. 37 (1984) 159-168.

16. Melsert R., Hoogerbrugge J. W. and Rommerts F. F. G.: The albumin fraction of rat testicular fluid stimulates steroid production by isolated Leydig cells. Molec. Cell. Endocr. 59 (1988) 221-231

17. Melsert R., Hoogerbrugge J. W. and Rommerts, F. F. G.: Albumin, a biologically active protein acting on Leydig cells. Molec. Cell. Endocr. 64 (1989) 35-44.

18. De Jong F. H.: Inhibin. Physiol. Rev. 68 (1988) 555-607.

19. Steinberger A. and Steinberger E.: Secretion of an FSH-inhibiting factor by cultured Sertoli cells. Endocrinology 99 (1976) 918-921.

20. Ultee-van Gessel A. M., Leemborg F. G., de Jong F. H. and van der Molen H. J.: In-vitro secretion of inhibin-like activity by Sertoli cells from normal and prenatally irradiated immature rats. $J$. Endocr. 109 (1986) $411-418$. 
21. Bicsak T. A., Vale W., Vaughan J., Tucker E. M., Cappel S. and Hsueh A. J. W.: Hormonal regulation of inhibin production by cultured Sertoli cells. Molec. Cell. Endocr. 49 (1987) 211-217.

22. Grootenhuis A. J., Timmerman M. A., Hordijk P. L. and de Jong F. H.: Inhibin in immature rat Sertoli cell conditioned medium: a $32 \mathrm{kDa} \alpha \beta-\mathrm{B}$ dimer. Molec. Cell. Endocr. 70 (1990) 109-116.

23. Hsueh A. J. W., Dahl K. D., Vaughan J., Tucker E., Rivier J., Bardin C. W. and Vale W.: Heterodimers and homodimers of inhibin subunits have different paracrine action in the modulation of luteinizing hormonestimulated androgen biosynthesis. Proc. Natn. Acad. Sci. U.S.A. 84 (1987) 5082-5086.

24. Morris P. L., Vale W. W., Vaughan J, and Bardin W.: Intragonadal modulators of immature Leydig cell function: inhibin-related peptides. In Programme and $A b$ stracts of the lOth Annual Testis Workshop, Baltimore, MD, U.S.A. (1988) Poster 33.
25. Grootenhuis A. J., Steenbergen J., Timmerman M. A., Dorsman A. N. R. D., Schaaper W. M. M., Meloen $R$. $H$. and de Jong F. H.: Inhibin and activin-like activity in fluids from male and female gonads: different molecular weight forms and bioactivity/immunoactivity ratios. J. Endocr. 122 (1989) 293-301.

26. Rommerts F. F. G., Molenaar R. and Van der Molen H. J.: Preparation of isolated Leydig cells. Meth. Enzym. 109 (1985) 275-288.

27. van der Vusse G. J., Kalkman M. L. and van der Molen H. J.: $3 \beta$-Hydroxy steroid dehydrogenase in rat testis tissue. Inter- and subcellular localization and inhibition of cyanoketone and nagarse. Biochim. Biophys. Acta 348 (1974) 404-414.

28. Lin T., Harrington Calkins J., Morris P. L., Vale W. and Bardin C. W.: Regulation of Leydig cell function in primary culture by inhibin and activin. Endocrinology 125 (1989) 2134-2140. 